\title{
A Theoretical Expansion of Talent Allocation Model: Evidence from Selected Developing Countries from 2014-2018
}

\author{
Rozita Moayedfar, Mohsen Madani Chafi
}

\begin{tabular}{|c|c|}
\hline & A B S T R A C T \\
\hline $\begin{array}{l}\text { Objective: } \mathrm{T} \\
\text { economic a }\end{array}$ & $\begin{array}{l}\text { bjective of this study is to propose a model for talent allocation to } \\
\text { ies and rent-seeking based on some effective factors. }\end{array}$ \\
\hline $\begin{array}{l}\text { Research Des } \\
\text { method base }\end{array}$ & $\begin{array}{l}\text { \& Methods: We examined the research model using the panel data } \\
\text { in data from selected developing countries in the years 2014-2018. }\end{array}$ \\
\hline $\begin{array}{l}\text { Findings: Ou } \\
\text { erty rights a } \\
\text { search's mo }\end{array}$ & $\begin{array}{l}\text { ults indicated that market size, firm scale, and the quality of prop- } \\
\text { ect the talent allocation based on the theoretical logic of our re- } \\
\text { ig. }\end{array}$ \\
\hline $\begin{array}{l}\text { Implications } \\
\text { about circum } \\
\text { firm scale in } \\
\text { ents' tenden } \\
\text { promote eco }\end{array}$ & $\begin{array}{l}\text { commendations: It seems necessary for an economy to worry } \\
\text { ices that influence the quality of property rights, market size, and } \\
\text { ition to human capital accumulation in order to reinforce the tal- } \\
\text { owards productive activities rather than rent-seeking; that is, to } \\
\text { ic growth. }\end{array}$ \\
\hline $\begin{array}{l}\text { Contribution } \\
\text { sources towa } \\
\text { plain how ma } \\
\text { between pro } \\
\text { rights model }\end{array}$ & $\begin{array}{l}\text { Value Added: Moving a step forward from the quality of human } \\
\text { s allocating them as "economy talents," we proposed a model to ex- } \\
\text { et size, firm scale, and quality of property rights affect talents' choice } \\
\text { ictive activities and rent-seeking, via Romer's quality of property } \\
\text { pansion. }\end{array}$ \\
\hline Article type: & research article \\
\hline Keywords: & allocation of talent; market size; firm scale; property rights \\
\hline JEL codes: & $\mathrm{E} 7, \mathrm{O} 3, \mathrm{O} 4$ \\
\hline Received: & Accepted: 29 September 2019 \\
\hline
\end{tabular}

\section{Suggested citation:}

Moayedfar, R., \& Madani, C.M. (2019). A Theoretical Expansion of Talent Allocation Model: Evidence from Selected Developing Countries from 2014-2018. Entrepreneurial Business and Economics Review, 7(4), 57-72. https://doi.org/10.15678/EBER.2019.070404 


\section{INTRODUCTION}

In the present competitive situation with incessant changes and innovations, the economies that achieve higher levels of prosperity are those which appreciate the important role of their human resources, which are skilful, knowledge-working, eminent, talented, and high-powered.

Among different skills, psychological features like intelligence or aptitude play a key role in individual development. In theories of economic development, not only the accumulation of human capital but also the way of capital allocation - especially the allocation of with high capabilities in economic, social, and cultural fields - attracts the attention of scholars and theoreticians. When skilful individuals become entrepreneurs, they develop technology and increase productivity. On the contrary, when they tend towards rent-seeking, it results in wealth redistribution rather than production (Jones, 1998; Jones \& Schneder, 2010).

Romer (2006) divides economic activities into two categories: productive activities (which increase production) and rent-seeking activities (which redistribute existing wealth). Murphy, Shleifer, and Vishny (1991) discuss that the rate of economic growth, in which talented people are involved in production activities, is higher than economic growth, in which talented people tend towards rent-seeking activities.

Therefore, it seems that one of the most important subjects for analysis is to determine the mechanisms that drive talents and how they should be allocated to economically productive activities.

Collins, McMullen, and Reutzel (2016) believe that the incentives imposed by institutions influence entrepreneurial behaviours; but some researchers focus on individual factors like intention and talent. Despite efficient institutions, during a systematic review of Baumol theory, Aeeni, Motavaseli, Sakhdari, and Mobini Dehkordi, (2019) reveal that the individual characteristics can lead talents to unproductive activities. Hmieleski and Lerner (2016) also address the individual characteristics in the tendency towards entrepreneurial activities.

While most studies focus on positive personality traits like optimism, dispositional positive affect, and generalized self-efficacy, Hmielski and Lerner (2016) try to highlight the dark aspects of personality and their relationship with entering the entrepreneurial activities. Their results show narcissism as the only personal character to be positively related to entrepreneurial intentions (Hmieleski \& Lerner, 2016).

Moreover, some studies largely focus on the role of institutions like property rights in the allocation of talents to productive vs unproductive activities like rent-seeking. Murphy et al. (1991) believe that the talent allocation to the production sector of the economy alongside property rights is influenced by market size and firm scale. Regarding this issue, the objective of the current article is to propose a model for talent allocation to economic activities and rent-seeking based on some effective factors. The current study uses Murphy et al. (1991) and Romer (2006) as the foundation, attempts to extend their theoretical ideas in order to provide a model that explains the way the talents would be allocated, and describes the factors affecting talent allocation. The current article is a novel theoretical and practical expansion, which is the first to include market size and firm scale in talent allocation to economic activities model (Romer, 2006) and examine the influence 
of these variables along with the quality of property rights on the allocation of talents either to the production sector or rent-seeking redistribution of production.

The remainder of this paper is organised as follows. First, we provide a theoretical background, then elaborate the theoretical model, and next discuss the results in detail. The last part concludes the paper.

\section{LITERATURE REVIEW}

As mentioned above, this study uses the protection of production and rent-seeking described by Romer (2006). According to Murphy et al. (1991), this study attempts to model the way different factors affect the talent allocation in research and development sector and raise the tendency of rent-seekers to employ resources only for wealth redistribution rather than production.

When some talents establish an institution, they distribute growth and innovation; however, when they turn into rent-seekers, they redistribute wealth and decrease growth and development (Natkhov \& Polishchuk, 2012). Acemoglu (1995) believes that the proportional benefit of productive and rent-seeking activities influences the allocation of talents in both of these activities. He believes that labour force selected their favourite career by contrasting the rewards and productivity functions of productive vs rent-seeking activities (Acemoglu, 1995).

In every society, there are innovative people who are steered towards great jobs by the power of such traits like greed, ambition, curiosity, and sympathy. When individuals have freedom in choosing their jobs, they select the one that allows them to show the maximum amount of their capabilities. Murphy et al. (1991) discuss the forces, which affected the choices of highly talented individuals, considering whether they choose sociallyproductive activities or not. In this regard, Murphy et al. especially emphasise three factors: individuals' capabilities' return, the scale of each sector (firm scale and market size), compensation contracts, and property rights. The larger the market size in which talents can achieve productivity, the higher the talents' tendency towards these activities. To sum up, clear property rights encourage productive activities, while legal rent-seeking activities (those supported by the government) or illegal rent-seeking raise the appeal to socially non-productive activities. From a broader perspective, we may conclude that the large market size, the capacity of firm development, and the quality of property can cause talents to tend towards economically productive activities (Murphy et al., 1991).

\section{The Allocation of Talent and Rent-Seeking}

According to Baumol (1990), individuals have two options. They can either strive to create wealth in the private sector or redistribute wealth through political and legal activities. Inspired by popular ideas of endogenous growth theory, we believe that the development of knowledge and technology not only occurs through research and development but also relates to entrepreneurship activities (Baumol, 1990).

Regarding entrepreneurship and its relation to productive activities, Holcombe (1998) refers to entrepreneurship as a process of providing opportunities for others to work, therefore considering it a productive activity (Holcombe, 1998). On the other hand, previous studies on productive economic activities often deal with the issue of rent-seeking. In this regard, Baumol (1990) claims that those activities that do not increase the wealth of 
society and only enhance their own proportion of existing wealth are called rent-seeking. Baumol believes the determining factors of entrepreneurial action are only institutional factors, but he does not notice how these factors lead talents to choose rent-seeking vs entrepreneurial activities (Aeeni et al., 2019).

Boudreaux, Nikolaev, and Holcombe (2018) highlight the role of institutions in leading entrepreneurs. They believe an inefficient institutional environment leads entrepreneurs to destructive activities and crowds out value-creating entrepreneurs.

In inefficient institutional environment, entrepreneurs encounter corruption that corrodes trust in governments, market institutions, and the rule of law. With corrupt institutions, profit opportunities come from rent-seeking; therefore, the resources are distorted towards capital projects that are more susceptible to rent-seeking (Boudreaux, Nikolaev, \& Holcombe, 2018).

Rent-seeking refers to the process of expending resources and efforts in order to politically preserve or transfer economic rights (Busse \& Hefeker, 2007). Rent-seeking is a rather new issue, which was first introduced by Krueger in 1974 (Samadi, Renani, \& Dallali-Esfahani, 2010; Tullock, 1967). Murphy et al. (1991) classify rent-seeking into private and public categories. Private rent-seeking includes robbery, piracy, illegal copy, and other forms of transferring wealth among private firms like capital gaining. Public rentseeking includes redistribution of income from the private sector to the government (e.g. taxation) or from the private sector to bureaucrats (e.g. bribery).

The influence of rent-seeking on society is pervasive. Besides developing inflation, poverty, inequality, and corruption, rent-seeking makes talents abandon production and appeal to unproductive activities or choose passiveness or migration (Acemoglu \& Verdier, 1998).

Regarding the effects of talents' inclination towards rent-seeking, Murphy et al. (1991) acknowledge that the allocation of talent to rent-seeking is destructive for several reasons. Firstly, if rent-seeking develops, it attracts the labour force and other resources, which decreases their income. A large portion of official bureaucracy in some less-developed countries confirms that. Secondly, taxes imposed because of rent-seeking on the production sector reduce the incentive for production and decrease the labour force income again. Finally, the allocation of most talents to the rent-seeking sector means that entrepreneurs have no power and, consequently, the growth rate of economy and technology will most probably reduce.

\section{Talent Allocation Factors}

By emphasising knowledge-based economy, modern economic ideas suggest that the most successful economy in the future will be the one that deals with the production and distribution of knowledge. Therefore, modern economic theories highlight the role of human capital in the production of knowledge and wealth more than ever (Nunn, 2007). Previous studies confirm the influence of talents' career choices on economic development. Murphy et al. (1991) state that the country's talents typically organise production. Thus, they could spread their ability advantage over a larger scale of production. Murphy et al. mention three major factors as the determinants of career choice and talent allocation. These factors include market size, firm scale, the quality of reward, compensation contracts, and the quality of property rights (Murphy et al., 1991). 


\section{Market Size}

From the macroeconomics perspective, the size of the market can influence a talent's choice of career between productive and rent-seeking activities. In fact, large markets or broad economic capacities of a country - besides other factors mentioned below - encourage outstanding people to allocate their talents to production, activate the maximum amount of their capabilities, and take advantages. Murphy et al. (1991) argue that if the official rent-seeking sector such as the government, religious institutions or army was very powerful in a country, rent-seeking could provide much privilege to those involved.

To sum up, we may say that - depending on its size and nature - the market competes with official rent-seeking activities as the indicators influence a talent's choice of productive or unproductive activities.

\section{Firm Scale}

Some jobs do not find chances for development in a specific society due to situational conditions. Such conditions include rules, cumbersome bureaucracy, customs, traditions, and culture, which bring about constraints for some occupations. Accordingly, we may conclude that the growth and development ability of a country's economic activities are the factors that affect the occupational choice of economic agents, especially talents. In this study, the ability of institutions' development was defined in terms of their size, so that an institution's size indicates its legal and situational capacity for developing economic activities.

In a limited context, which does not allow the institution to develop or grow, rent-seeking and unproductive activities provide alternative opportunities for talents. According to Murphy et al. (1991), in many less-developed countries, legal constraints on the establishment and development of private institutions or corporations, e.g. industrial capacity licensing, is a limitation imposed by the government. This limitation reduces the appeal to entrepreneurship. For example, when official rent-seekers levy heavy taxes on entrepreneurs, owners become suppressed and appeal to rent-seeking (Murphy et al., 1991).

\section{The Quality of Property Rights}

Talents need to preserve their ability returns and be sure about receiving rewards or compensations. In weak-property-rights countries, talents are greatly incentivised to rentseeking. Actually, when the official rent-seeking sector - like high-ranking officials or the army - is very powerful, it expropriates a huge amount of money freely or even legally. Be levying high taxes on economic activities or a reformulation of property rights in favour of the rent-seeking sector, official rent-seeking leaves less room for productive economic activities and frustrates talents. Besides official rent-seeking, non-official rents like bribery and robbery disturb the economic and social safety and prepare grounds for an unfair redistribution of wealth. In such conditions, talents have only one choice of rent-seeking activities and, thus, which engenders the inappropriate allocation of talents in society.

Berdiev and Saunoris (2018) focus on the effects of corruption on entrepreneur allocation; they find that corruption deters entrepreneurs in formal sectors and promotes entrepreneurship in informal sectors; we know that corruption is the other meaning of domestic institutions' weakness and so, in this situation, property rights are not transparent. 
Murphy et al. (1991) indicate the role of property rights as one of the factors that affect the allocation of talents. They find that if the returns on inventions are not preserved through patent and privileges for entrepreneurs, productive activities like entrepreneurship will lose their approval.

Our investigation shows that the allocation of talents to rent-seeking and productive activities is influenced by three categories:

- institutional,

- individual,

- economic.

Until now, most researchers focused on the first two categories, whereas we entered in our literature review market size and firm scale as economic factors and concluded that these two variables - along with property rights - influence the allocation of talents. Therefore, we propose the following hypotheses:

H1: The improvement of property rights index affects the allocation of talents to production activities positively and significantly.

H2: The increase of firm scale affects the allocation of talents to production activities positively and significantly.

H3: The increase of market size affects the allocation of talents to production activities positively and significantly.

\section{MATERIAL AND METHODS}

\section{Data}

Measuring the variables of our model is the next important step to find practical results. Since entrepreneurship is the core of every productive activity, the use of Global Entrepreneurship Index (GEI) as a multidimensional entrepreneurship index can be an appropriate proxy for the number of talent allocation to economic activities in countries. GEI is published by the Global Entrepreneurship and Development Institute every year from 2014 (Acs et al. 2018).

According to Chakrabarti (2001), market size can be measured by per capita Gross Domestic Product while firm scale can be quantified with the data of company market capitalisation. World bank annually publishes the market capitalization of listed domestic companies and the number of listed companies in countries, and these data helped us to measure the average scale per firm as follows (database, 2018):

where:

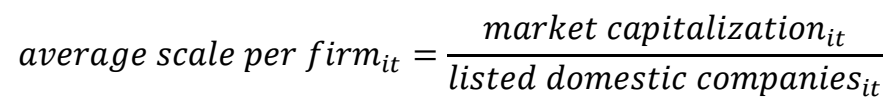

$$
i, t \text { - respectively indicate country and time. }
$$

The international property rights index (IPRI) also is a standard quantitative criterion for measuring the property right variable in countries. Property right index is prepared based on three main indicators: 1) Legal and Political Environment (LPE), 2) Physical Property Rights (PPR), and 3) Intellectual Property Rights (IPR) by Property Rights Alliance 
(PRA; Levy carciente, 2018). These three main indicators contain ten sub-indicators conceptually identical with the property right variable.

Our approach applies panel data analysis for 27 selected developing countries that consist of: Iran, Malaysia, Saudi Arabia, Turkey, Egypt, Indonesia, India, Nigeria, Jordan, Thailand, Morocco, Chaina, Colombia, Russia, Peru, Hungary, Argentina, Panama, Vietnam, Sri Lanka, Croatia, Kazakhstan, Lebanon, Oman, Philippines, Qatar, and the United Arab Emirates in years 2014-2018. We intended to prepare an empirical estimation for all developing countries but the limited availability of data forced us to select only these 27 developing countries.

\section{Theoretical Model}

\section{Modelling the Quality of Property Rights}

This model supposes that there are active groups of producers and rent-seekers in any economy; the latter attempt to legally or illegally intercept the returns of producers. Therefore, taking rent-seekers into account, the number of employed individuals in the research and development sector can be considered $a_{L}-R$, in which $\mathrm{R}$ is the number of rent-seekers. Producers spend $f$ unit of time on preserving their product while the rest (1-f) on production. Here, we apply two modifications to Romer's model: first, unlike Romer (2006), we do not consider the average production to be an identity function parallel to 1-f, but we introduce the average production of every producer as (1-f)Y so that the producer spends 1-f on production. Therefore, production reduces as much as $\mathrm{fY}$ (the time spent on protection). In fact, if the producer spends all their time on production $(f=0)$, the production will be equal to $Y$ on average. On the other hand, $f$ is a function of $Y$ besides $R$, because it is logical to suppose that the higher the individual's returns, the more significant proportion of the income spent on protection. Therefore, we can say that $f(R, Y)$ and $f_{Y} \geq 0$.

A proportion of this production goes to the rent-seeker because, despite protection, there is the possibility of the appropriation of producers' returns by rent-seekers. The proportion of the product appropriated by rent-seekers is indicated by L. In this case, L equals $\mathrm{L}(\mathrm{f}, \mathrm{R})$, so that $L_{f} \leq 0$ and $L_{R} \geq 0$. Regarding the second-order derivatives of $\mathrm{L}$, we suppose that the protection benefit is decreasing for the producer. This means that if $f$ increases, the benefit of $f$ decreases $\left(L_{f f} \geq 0\right)$. Furthermore, the higher the number of rent-seekers, the lower their amount of benefit. This means that the second-order derivative of $L$ to $\mathrm{R}$ is negative $\left(L_{R R} \leq 0\right)$. Moreover, if there is no rent-seeker, then no proportion of income is allocated to rent-seekers. Thus, we have $L(f, 0)=0$. Regarding the second-order derivative, the higher the number of rent-seekers, the lower the compensation of the product protection $\left(L_{f R} \leq 0\right)$.

Based on the principles of microeconomics, if the producer's return is higher than the rent-seeker's return, the proportion of those who appeal to productive activities increases, and vice versa. As a matter of fact, talents incline towards those activities that reward them more.

The model extended in this study follows Romer's assumptions that the return of production is an identity function of the production function. The return of every producer and every rent-seeker is, respectively: 


$$
\begin{gathered}
{[1-L(f(R, Y), R)][1-f(R, Y)] Y} \\
(1-R) L[f(R, Y), R][1-f(R, Y)] Y \\
R
\end{gathered}
$$

In this way, equilibrium is achieved in the Equation (4), in which $\mathrm{R}$ is "equilibrium R:"

$$
[1-L(f(R, Y), R)][1-f(R, Y)] Y=\frac{(1-R) L[f(R, Y), R][1-f(R, Y)] Y}{R}
$$

The left side shows the producer's return, in which $[1-f(R, Y)]$ decreases with an increase in R. Regarding the other statement $[1-L(f(R, Y), R)]$, we cannot have an accurate prediction of the behaviour of $L$ with the increase in $R$; although $L$ is an increasing function of $R$ and a reducing function of $f$, and $f$ itself increases with an increase in R. However, in general, the producer's return decreases when the number of rent-seekers enhances. The right side shows rent-seekers' returns that decrease with an increase in R. 1-f and 1-R on the right side decrease with an increase in R. However, whether $L$ becomes an increasing or decreasing function of $R, L / R$ will be a function relative to $R$. In this fraction the increase in the denominator $(R)$ is always more than that in the numerator $(L)$ due to the fact that $L$ obeys the principle of decreasing returns relative to $R$. Moreover, when $R=1$, rent-seekers' returns equal zero. This means that when there is no producer, rent-seekers intercept no value.

When the economic system experiences an increase in the quality of property rights, it means that the returns of producers are protected through some policies that legally retake what was grabbed by the rent-seekers. Next, the confiscated properties can be distributed among individuals by the government. This action does not affect the curve of producer's returns, but only affects the curve of rent-seekers' income.

The possibility of disclosure leads to a decrease in rent-seekers' expected income for a specific $R$. This affects the curve of rent-seekers' income and turns it downwards. As illustrated in Figure 1, the curve that indicates rent-seekers' income turns downwards. It is clear that the decrease in $R$ is more than the amount needed for preserving rent-seekers' income at the primary level. When $R$ reduces, the appeal of production increases which, in turn, leads to a fall of $R$. Moreover, the equilibrium point shifts from $A$ to $C$ (Figure 1). Although the equilibrium income of producers and rentseekers in Point $C$ is higher than the equilibrium income before disclosure, rentseekers' expected income has decreased, and at this point, the proportion of rentseekers has decreased as well. As Figure 1 indicates, in the state before disclosure, rentseekers' income at point $R_{2}$ on the primary curve of rent-seekers' income enjoys a higher level. On the other hand, when $R$ diminishes, producers naturally allocate fewer resources to protection; therefore, producers' income increases. The important point here is that if we return rent-seekers' income to its pre-disclosure state, the proportion of rent-seekers does not return to its previous point. Point B demonstrates this state so that - under these conditions - the appeal of rent-seeking has decreased.

Therefore, we may say that the government's support for producers - in the form of enhancing the quality of property rights and anti-rent actions - positively affects talents' inclination towards production and the decrease of rent-seekers' proportion. 


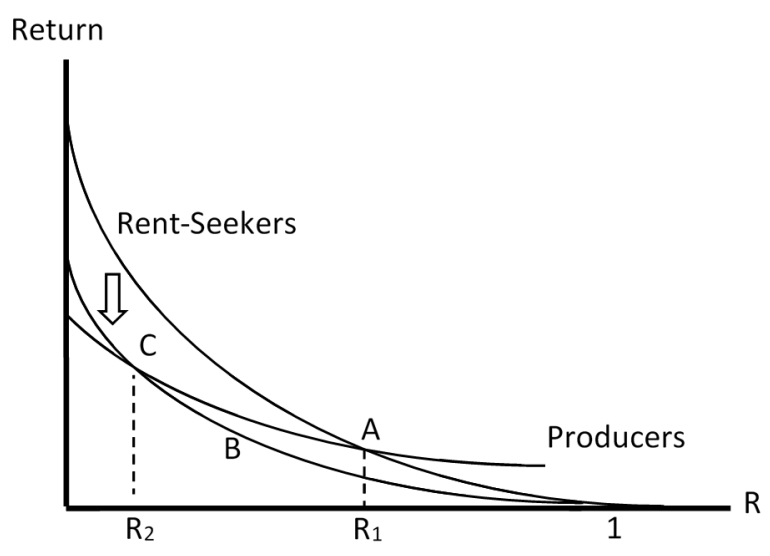

Figure 1. Effects of the property rights quality Source: Romer, 2006, p. 159.

\section{Modelling Market Size and Firm Scale}

Now, putting forward a new idea, we extend the model to show the effects of changes in market size and firm scale proportionally to the number of rent-seekers. Based on this, we suppose that firms encounter an increase in their market size; so the demand will grow on average and - based on the principles of microeconomics - the upwards turn of the curve of demand leads to the creation of another equilibrium point with higher levels of demand and supply of products or services.

Considering the increase in demand in a competitive market, the firm should increase its production to achieve a new equilibrium Y. According to a production function, the scope of the labour force - as an indicator of firm scale - should increase.

The increase in market size and firm scale makes a new Y. Now, it is time to analyse the Equation (4) and examine changes in the ratio of rent-seekers when $Y$ increases due to the increase in market size and firm scale. For this purpose, we simplify the Equation (4) as follows:

$$
L[f(R, Y), R]=R \rightarrow L[f(R, Y), R]-R=0
$$

The Equation (5) indicates that in order for producers' return to equal rent-seekers' revenue, a portion of marginal revenue grabbed by rent-seekers $(L)$ should equal the rent-seekers' portion.

Now, considering the increase in $Y$, in order to know how the equilibrium $R$ changes, we calculate the partial derivative of Equation (5) with respect to $R$ :

$$
\frac{\partial L}{\partial f} \cdot \frac{\partial f}{\partial R} \cdot \frac{d R}{d Y}+\frac{\partial L}{\partial f} \cdot \frac{\partial f}{\partial Y}+\frac{\partial L}{\partial R} \cdot \frac{d R}{d Y}-\frac{d R}{d Y}=0 \rightarrow \frac{d R}{d Y}=\frac{\frac{\partial L}{\partial f} \cdot \frac{\partial f}{\partial Y}}{\left(1-\frac{\partial L}{\partial f} \cdot \frac{\partial f}{\partial R}-\frac{\partial L}{\partial R}\right)}
$$

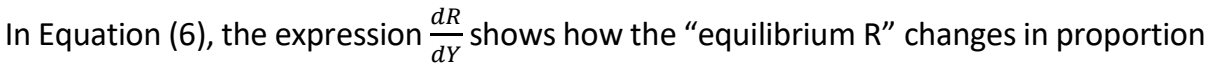
to $Y$. In fact, when the right side of the equation is negative, it reveals that an increase in $Y$ causes a reduction in the equilibrium $R$, and a reduction in the rent-seekers' proportion. 
Now, we examine the Equation (6) in order to find out the sign of its right side. We previously explained that $\frac{\partial L}{\partial f}$ was negative and $\frac{\partial f}{\partial Y}$ was positive; therefore, the sign of the numerator will be negative. As mentioned before, in the denominator, $\frac{\partial L}{\partial f}$ is negative, $\frac{\partial f}{\partial R}$ is positive based on the model so, consequently, $\frac{\partial L}{\partial f}, \frac{\partial f}{\partial R}$ will be negative.

Since $\frac{\partial L}{\partial R}$ is positive based on the model's presupposition, the denominator sign on the right side of Equation (6) is not clearly specified. However, this denominator sign can show that, when $\mathrm{R}$ is high regarding the decreasing outcome, the amount of $\frac{\partial L}{\partial R}$ is lower than $1-\frac{\partial L}{\partial f} \cdot \frac{\partial f}{\partial R}$. In this case, the denominator of Equation (6) will be positive, while the whole statement on the right side will be negative. This indicates the reduction in the equilibrium $\mathrm{R}$ by an increase in $\mathrm{Y}$.

Therefore, we may say that - at least in countries with a large number of rent-seekers - the increase in market size and firm scale leads on average to a reduction of the rentseekers' proportion and, consequently, results in talents' inclination towards production.

\section{RESULTS AND DISCUSSION}

Our theoretical model estimates the relationship between property rights index, firm scale, and market size as the effective factors, and the allocation of talents status to production activities logic.

Thus, the specification of our empirical model is:

$$
\begin{gathered}
\text { Allocation of talent } \\
+\beta_{3}=\beta_{0}+\beta_{1} \text { Market size }_{i t}+\beta_{2} \text { Firm scale }_{i t}+ \\
+U_{i t}
\end{gathered}
$$

In the model (7) "Allocation of talents" means "Global Entrepreneurship Index" for country $i$ in year $t$ with the range between 0 to 100, "Market size" means "per capita GDP" for country $\mathrm{i}$ in year $\mathrm{t}$ in terms of USD, "Firm scale" means "Average Market Capitalisation" per firm for country $i$ in year $t$ in billion USD, and "Property rights" means "International Property Rights Index" for country $i$ in year $t$ with the range between 0 to 10 .

The results of F-Limer (Chaw test) reveal that the null hypothesis is rejected (chi2 $=8.177, \mathrm{df}=(3,92), p$-value $=0.0001$; Table 1$)$. Therefore, we must use Hausman test to investigate the fixed effects estimation in comparison with random effects estimation. The result of Hausman test shows that the null hypothesis is rejected (chi2 $=20.182, \mathrm{df}=3, p$-value $=0.0002$ ), while Fixed effects $(\mathrm{FE})$ estimation is preferred to Random effects estimation. We show the results in Table 2.

Moreover, in order to check for the heteroscedasticity error across our panel data, we used the likelihood ratio test procedure recommended by Wiggins and Poi (2001). Table 3 represents the result of Wiggins and Poi test across our panel data.

Based on the results of Wiggins and Poi likelihood ratio test, we failed to reject the null hypothesis as there is no heteroscedasticity error across our panel data. The autocorrelation in residuals was assessed by Breusch-Godfrey serial correlation LM test as well, and the results revealed the presence of first-order error. Table 4 shows the results of the autocorrelation test in residuals. 
Table 1. The results of F-Limer (Chaw test)

Redundant Fixed Effects Tests; Equation: Untitled; Test period fixed effects

\begin{tabular}{|l|c|c|c|}
\hline \multicolumn{1}{|c|}{ Effects Test } & Statistic & d.f. & $\boldsymbol{p}$-value \\
\hline Period F & 8.177000 & $(3,92)$ & 0.0001 \\
\hline
\end{tabular}

Period fixed effects test equation: Dependent Variable: GEI; Method: Panel EGLS (Period weights); Sample (adjusted): 2014 2017; Periods included: 4; Cross-sections included: 27; Total panel (unbalanced) observations: 99; Use pre-specified GLS weights.

Source: own calculation in E-views7.

Table 2. The result of Hausman test

Correlated Random Effects-Hausman Test; Equation: Untitled; Test period random effects.

\begin{tabular}{|l|l|l|c|}
\hline \multicolumn{1}{c|}{ Test Summary } & Chi-square & d.f. & $\boldsymbol{p}$-value \\
\hline Period random & 20.181939 & 3 & 0.0002 \\
\hline
\end{tabular}

** WARNING: estimated period random effects variance is zero.

Period random effects test comparisons:

\begin{tabular}{|l|c|l|l|l|}
\hline \multicolumn{1}{|c|}{ Variable } & Fixed & \multicolumn{1}{c|}{ Random } & Var (Diff.) & \multicolumn{1}{c|}{ Prob. } \\
\hline GDP_PER_CAPITA1 & 0.426583 & 0.441733 & 0.000238 & 0.3263 \\
\hline MARKET_CAPITALIZATION1 & 1.181523 & 1.036471 & 0.009769 & 0.1422 \\
\hline PROPERTY_RIGHTS & 3.067403 & 2.694473 & 0.024042 & 0.0162 \\
\hline PeriOdrandOm
\end{tabular}

Period random effects test equation: Dependent Variable: GEI; Method: Panel Least Squares; Date: 09/07/18 Time: 20:10; Sample (adjusted): 2014 2017; Periods included: 4; Cross-sections included: 27; Total panel (unbalanced) observations: 99.

Source: own calculation in E-views7.

Table 3. The result of Wiggins and Poi likelihood ratio test

\begin{tabular}{|c|c|c|}
\hline Equation No. & Value & P-value \\
\hline 11 & 2.30 & 0.51 \\
\hline
\end{tabular}

Source: own calculation in E-views7.

Table 4. The result of Breusch-Godfrey serial correlation LM test

\begin{tabular}{|c|c|c|c|}
\hline Equation No. & Type of test & Value & P-value \\
\hline \multirow{2}{*}{11} & Chi-square & 29.65 & 0.00 \\
\hline & Fisher & 129.48 & 0.00 \\
\hline
\end{tabular}

Source: own calculation in E-views7.

As a result, we entered the one lagged of residual component into our empirical model to correct the first-order error and then estimated our empirical model for selected countries in the years 2014-2018. Table 5 shows the results and Table 6 demonstrates the coefficient of equation (7).

A systematic review of 76 articles published from 2001 to 2018 analysed Baumol theory and emphasised the importance of incentives presented by institutions for entrepreneurial behaviour (Aeeni et al., 2019). This and many other studies about talent allocation to productive and entrepreneurial activities formed our literature review. The common point of our research and these studies is "property rights" as an effective institutional factor. 
Table 5. The results of the estimation of the coefficient of equation (11)

\begin{tabular}{|c|c|c|c|c|}
\hline \multicolumn{5}{|c|}{$\begin{array}{l}\text { Dependent Variable: GEI; Method: Panel Least Squares; Date: 09/10/18 Time: 22:28; } \\
\text { Sample (adjusted): } 2015 \text { 2017; Periods Included: 3; Cross-sections included: 27; Total } \\
\text { panel (unbalanced) observations: 72. }\end{array}$} \\
\hline Variable & Coefficient & Std. Error & t-Statistic & Prob. \\
\hline GDP_PER_CAPTA1 & 0.490529 & 0.062343 & 7.868211 & 0.0000 \\
\hline MARKET_CAPITALIZATION1 & 1.233491 & 0.644495 & 1.913887 & 0.0600 \\
\hline PROPERTY_RIGHTS & 3.566829 & 0.646148 & 5.520138 & 0.0000 \\
\hline RESL(-1) & 0.770295 & 0.071310 & 10.80204 & 0.0000 \\
\hline $\mathrm{C}$ & 9.427953 & 3.113400 & 3.028186 & 0.0035 \\
\hline \multicolumn{5}{|c|}{ Effects Specification } \\
\hline \multicolumn{5}{|l|}{ Period fixed (dummy variables) } \\
\hline R-squared & 0.876267 & \multicolumn{2}{|c|}{ Mean dependent var } & 34.15062 \\
\hline Adjusted R-squared & 0.864846 & \multicolumn{2}{|c|}{ S.D. dependent var } & - \\
\hline S.E. of regression & 3.735223 & \multicolumn{2}{|c|}{ Akaike info criterion } & 5.565658 \\
\hline Sum squared resid & 906.8731 & \multicolumn{2}{|c|}{ Schwarz criterion } & 5.787000 \\
\hline Log likelihood & -193.3637 & \multicolumn{2}{|c|}{ Hannan-Quinn criter. } & 5.653775 \\
\hline F-statistic & 76.72080 & \multicolumn{2}{|c|}{ Durbin-Watson stat } & 1.496140 \\
\hline Prob(F-statistic) & 0.000000 & \multicolumn{2}{|c|}{-} & - \\
\hline
\end{tabular}

Source: own calculation in E-views7.

Table 6. The results of the estimation of the model

\begin{tabular}{|l|c|c|c|}
\hline \multicolumn{1}{|c|}{ Variables } & Coefficient & T-test & P-value \\
\hline$\beta_{0}$ & 9.43 & 3.03 & 0.004 \\
\hline Market size & 0.49 & 7.87 & 0.000 \\
\hline Firm scale & 1.23 & 1.91 & 0.060 \\
\hline Property rights & 3.57 & 5.52 & 0.000 \\
\hline Residual (-1) & 0.77 & 10.80 & 0.000 \\
\hline R-squared: 0.88; Adjusted R-squared: 0.86; Prob (F-statistic): 0.00. \\
\hline
\end{tabular}

Source: own calculation in E-views7.

Berdiev and Saunoris (2018) show the significant negative effect of corruption - as a weakness of property rights - on formal entry to entrepreneurship in 60 countries in 2001-2010 (Boudreaux et al. (2018) emphasise the significant positive relationship between corruption and the concentration of firms in corruptible activities and rent-seeking by using 30,000 evidence of convictions with significant variation across districts and over time in the United States of America (Boudreaux et al., 2018). The study by Natkhov and Polishchuk (2012) also focuses on the role of institutions in talent allocation, and its results show a significant positive relationship between the quality of institutions and the tendency of talents to educate in engineering and science instead of law. This study used Murphy et al.'s (1991) study that scrutinises the combination of talent education as an appropriate proxy for talent allocation status in the economy (Murphy et al., 1991; Natkhov \& Polishchuk, 2012). Similar to these studies, we analysed the effect of property rights on talents' inclination towards productive activities, and we noticed that the strongest effect belongs to property rights. 
Our review revealed no mention of two other factors used in our research: "firm scale" and "market size." Our results showed that the coefficients of the model affect talent allocation to production activities significantly and positively. Each unit increase in firm scale and market size increases the allocation of talent index by 1.23 and 0.49 , respectively.

As we mentioned above, rent-seeking activities include any activities that waste economic resources and transfer wealth from productive labourers to rent-seekers. Every economy in which productive labour is not sufficiently supported witnesses the expansion of rent-seeking activities and free actions of rent-seekers, while talents will have a strong inclination towards rent-seeking awards.

Therefore, on the one hand, one should support innovative thinking on the way towards its transformation into products and then into wealth, while on the other hand, one should limit rent-seeking activities, including capital gains, robbery, piracy, copyright infringement, and redistribution of income from the private sector to the government (e.g. tax-taking) or from the private sector to bureaucrats (e.g. bribery).

\section{CONCLUSIONS}

Accumulation of human resources, especially talents, is of great importance not only for universities but also for policymakers. Talents' inclination towards the productive sector of the economy and the quality of their allocation influence the economy in general and the indicators of economic growth in particular. In fact, the activities selected by talents, based on the economic situation of the society and social factors, have great effects on a country's development process. Thus, the present study focused on the factors that affect this tendency, and it attempted to propose an extended model in order to indicate that talents' inclination towards the productive sector of the economy is influenced not only by property rights quality but also by market size and firm scale at the macro-economic level.

In this process, the marginal revenue of rent-seekers and producers determine the rate of allocation of the talent to either rent-seeking or productive activities. An increase in the quality of property rights, firm scale, and market size leads to a higher appeal of talents to the production sector and reduces the proportion of rent-seekers.

Therefore, each policy that limits rent-seeking gains and facilitates productive activities is recommended. Increasing the cost of speculation activities by taxing these activities, limiting bureaucratic process and regulations, and rating the credibility of persons helps to heighten the efficiency of institutions and transparency of property rights. Furthermore, market expansion and firm scale are two interacting factors related to the economic function at macro and micro levels. Hence, we recommend that policymakers consider the effect of their policies on market size and firm scale.

We faced limitations in selecting the appropriate indices for talent allocation, the quality of property rights, and the availability of data for developing countries. Moreover, we supposed that $\frac{\partial L}{\partial R}$ (the slope of the curve $L$ to $\mathrm{R}$ ) is smaller than $\left(1-\frac{\partial L}{\partial f} \cdot \frac{\partial f}{\partial R}\right.$ ) which is true only for countries with a large number of rent-seekers.

Future studies should focus on finding a more appropriate index for talent allocation, which would include the allocation of talents to rent-seeking activities. Furthermore, this study considered the fact that $f$ depends both on $R$ and $Y$, but it seems that $\frac{\partial f}{\partial R}$ can be re-examined in another study. 


\section{REFERENCES}

Acemoglu, D. (1995). Reward Structures and the Allocation of Talent. European Economic Review, 39(1), 17-33. https://doi.org/10.1016/0014-2921(94)00014-Q

Acemoglu, D., \& Verdier, T. (1998). Property Rights, Corruption and the Allocation of Talent: a General Equilibrium Approach. The Economic Journal, 108(450), 1381-1403. https://doi.org/10.1111/1468-0297.00347

Ács Z.J., Szerb L., Lafuente E., \& Lloyd, A. (2018). The Global Entrepreneurship and Development Index. Retrived from https://thegedi.org/2018-global-entrepreneurship-index/ on May, 2019.

Aeeni, Z., Motavaseli, M., Sakhdari, K., \& Mobini Dehkordi, A. (2019). Baumol's Theory of Entrepreneurial Allocation: A Systematic Review and Research Agenda. European Research on Management and Business Economics, 25(1), 30-37. https://doi.org/10.1016/j.iedeen.2018.09.001

Baumol, W.J. (1990). Entrepreneurship: Productive, Unproductive, and Destructive. Journal of Business Venturing, 11(1), 3-22. https://doi.org/10.1016/0883-9026(94)00014-X

Berdiev, A.N., \& Saunoris, J.W. (2018). Corruption and Entrepreneurship: Cross-Country Evidence from Formal and Informal Sectors. Southern Economic Journal, 84(3), 831-848. https://doi.org/10.1002/soej.12250

Boudreaux, C.J., Nikolaev, B.N., \& Holcombe, R.G.(2018). Corruption and Destructive Entrepreneurship. Small Business Economics, 51(1), 181-202. https://doi.org/10.1007/s11187-017-9927-x

Busse, M., \& Hefeker, C. (2007). Political Risk, Institutions and Foreign Direct Investment. European Journal of Political Economy, 23(2), 397-415. https://doi.org/10.1016/j.ejpoleco.2006.02.003

Chakrabarti, A. (2001). The Determinants of Foreign Direct Investments: Sensitivity Analyses of Cross-Country Regressions. Kyklos, 54(1), 89-114. https://doi.org/10.1111/1467-6435.00142

Collins, J.D., McMullen, J.S., \& Reutzel, C.R. (2016). Distributive Justice, Corruption and Entrepreneurial Behavior. Small Business Economics, 47(4), 981-1006. https://doi.org/10.1007/s11187-016-9751-8

Database, World Federation of Exchanges. (2018). Market capitalization of listed domestic companies. Retrived from https://data.worldbank.org/indicator/CM.MKT.LCAP.GD.ZS on April, 2019.

Hmieleski, K.M., \& Lerner, D.A. (2016). The Dark Triad and Nascent Entrepreneurship: An Examination of Unproductive versus Productive Entrepreneurial Motives. Journal of Small Business Management, 54(S1), 7-32. https://doi.org/10.1111/jsbm.12296

Holcombe, R.G. (1998). Entrepreneurship and Economic Growth. The Quarterly Journal of Austrian Economics, 1(2), 45-62. https://doi.org/10.1007/s12113-998-1008-1

Jones, C.I. (1998). Introduction to economic growth (1st ed.). New York, NY: W.W. Norton.

Jones, G., \& Schneder, W.J. (2010). IQ in the Production Function: Evidence from Immigrant Earnings. Economic Inquiry, 48(3), 743-755. https://doi.org/doi:10.1111/j.1465-7295.2008.00206.x

Levy-Carciente, S. (2018). International property rights index. Retrieved from Property Rights Alliance: https://www.internationalpropertyrightsindex.org/countries on May, 2019.

Murphy, K.M., Shleifer, A., \& Vishny, R.W. (1991). The Allocation of Talent: Implications for Growth. Quarterly Journal of Economics, 106(2), 503-530.

Natkhov, T., \& Polishchuk, L. (2012). Institutions and the Allocation of Talent. Higher School of Economics. https://doi.org/ 10.2139/ssrn.2070084

Nunn, N. (2007). Historical Legacies: A Model Linking Africa's Past to Its Current Underdevelopment. Journal of Development Economics, 83, 157-175. https://doi.org/ 10.1016/j.jdeveco.2005.12.003

Romer, D. (2006). Advanced macroeconomics (3rd ed.). Boston, MA: McGraw-Hill. 
Samadi, A.H., Renani, M., \& Dallali-Esfahani, R. (2010). The Concept and Economic Effects of Property Rights: an Institutional Approach. Private Law Studies, 40, 183-202.

Tullock, G. (1967). The Welfare Costs of Tariffs, Monopolies and Theft. Economic Inquiry, 5(3), 224232. https://doi.org/ 10.1111/j.1465-7295.1967.tb01923.x

Wiggins, V., \& Poi, B. (2001). Testing for Panel-Level Heteroskedasticity and Autocorrelation. Retrived from StataCorp FAQs: https://www.stata.com/support/faqs/statistics/panel-level-heteroskedasticity-and-autocorrelation/ on April 2019. 


\section{Authors}

The contribution of co-authors is equal and can be expressed as $50 \%$ for each of the authors: $R$. Moayedfar proposed the main idea of this study, developed the mathematical framework of the model, and wrote the manuscript. M. Madani Chafi reviewed the literature for relevant studies and contributed in the writing of the manuscript. Both authors read and approved the final manuscript.

\section{Rozita Moayedfar}

Bachelor of Economic Sciences (University of Isfahan, Iran); Master in Economic Development and Planning (Alzahra University, Iran); PhD in Economic Sciences (University of Isfahan, Iran). Her research interests include macroeconomics, economic growth, regional economics, and social capital. Correspondence to: Assistant Professor Rozita Moayedfar, PhD, Department of Economics, University of Isfahan, Azadi square, Postal code: 8174673441, Isfahan, Iran, e-mail: r.moayedfar@ase.ui.ac.ir or moayedfar.r@gmail.com

ORCID (1) http://orcid.org/0000-0002-5996-9380

\section{Mohsen Madani Chafi}

Bachelor of Electrical Engineering (Islamic Azad University, Abhar Branch, Iran); Master in Economic Sciences.

Correspondence to: Mohsen Madani Chafi, Department of Economics, University of Isfahan, Azadi square, Postal code: 8174673441, Isfahan, Iran; e-mail: mohsen.madani.c@gmail.com ORCID (1) http://orcid.org/0000-0002-8498-9092

\section{Acknowledgements and Financial Disclosure}

We would first like to thank Dr. Mehdi Toghyani, Assistant Professor of the Department of Economics at the University of Isfahan, for his valuable advice. We also acknowledge Dr. Shekoufeh Farahmand, Associate Professor of the Department of Economics at the University of Isfahan, and Dr. Mahsa Ghandehari, Associate Professor of the Department of Management at the University of Isfahan for their beneficial comments. The authors declare that they have no conflict of interests.

\section{Copyright and License}

This article is published under the terms of the Creative Commons Attribution - NoDerivs (CC BY-ND 4.0) License http://creativecommons.org/licenses/by-nd/4.0/

Published by the Centre for Strategic and International Entrepreneurship - Krakow, Poland 